\title{
Research on Gombrich's Academic Affinitive Community Based on Data Mining
}

\author{
Jing $\mathrm{Ye}^{*}$ \\ College of Humanities, Zhejiang Shuren University. No. 8 Shuren Street, Hangzhou, Zhejiang, China \\ ${ }^{*}$ Corresponding author
}

\begin{abstract}
From the knowledge exchange and influence angle, taking bibliometrics as the research methods, the author selected the journal papers which cited Gombrich academic literatures as the research object. Based on the literature data mining, this article described the academic affinitive relationships and characteristics between Gombrich and other scholars in the related fields of international art history. The main finding is Gombrich's core community which can be summarized as six research groups: iconology research group of Warburg school, philosophy research group of analytic aesthetics, psychological research group of visual \& perceptual theory, research group of psychoanalysis, semiotics research group of post-structuralism, Italian art masters group in different periods. This study finally reveals Grombrich's significant academic status and influence, and provides a new method for the study of academic key figures and their affinitive communities in the Arts and Humanities.
\end{abstract}

Keywords-Gombrich; data mining; academic affinitive community

\section{INTRODUCTION}

"Two great scholars who set the art study standard of the twentieth century were born on the same day-March 30th, The legendary Erwin Panofsky was born in 1892, Sir Ernst H. J. Gombrich who enjoys the reputation of the Socratic Scholar was born in 1909 [1].Ernst Hans Josef Gombrich (1909-2001) is a famous British esthetician and art historian, an outstanding figure in the world art history. His academic thoughts and research methods bring great impact in the history study of world art. He also has significant academic characteristic of intersection and integration of different disciplines. Although since 1940 s, the voice of disciplines stabilization has become stronger, Gombrich still adhere to treating the history of art as a discipline with great range that researchers always need to study deeper and further [2].

The academic community means an academic research group which is constituted by the researchers who engaged in similar or the same academic research area. The community mainly involved with the activities in any specific academic areas. Academic community plays a leading role in the study area which performs the major functions such as academic innovation, inheritance, diffusion, evolution and prosperity.

From academic literature structure and academic affinity, the academic community can be expressed through the co-cited relationship between the scholars. And it will develop chronically by literature citation, cited status and the situation of co-cited based on Kaplan's hypothesis of citation normative theory [3] and Smith's citation norm theory [4].The study of the academic community can clarify the academic relationship between scholars, providing research background and research basis for their academic exchanges and cooperation, academic diffusion and influence, which is conducive to the sustainable development of the research while good for academic innovation and generating cluster effect.

This paper mainly studies the relationship of Gombrich's academic affinitive community, which refers to a collection of the authors who have high similarity on the research background or research topics with Gombrich. They have a certain correlation and similarity with Gombrich's academic point of view. Furthermore, Gombrich's academic communities can also be found through co-cited authors so as to find out the whole knowledge expansion, thoughts integration and discipline development in the process of academic thought flowing and influence.

\section{DATA STATISTICS}

Selecting three sub-databases as the data source from citation Index database of "Web of Science"(SCI-E, SSCI, A\&HCI), then retrieving all documents (1900-2015) which the "cited author" is "Gombrich", a total of 5486 papers can be found after articles duplicate removal.

By using statistical software and manual screening, we use Bibexcel in 5486 papers through context extraction, duplicate removal and analysis, which allow us to get a list of high frequency co-cited authors, as shown in Table I.

It shows that the higher the co-cited frequency between authors, the closer of their relationships. The higher the correlation of their study subjects, the affinitive relationships between them are much closer. The list in Table I represents authors who co-cited with Gombrich have at least 160 times. From the table we can see that Erwin Panofsky, Nelson Goodman and Rudolf Arnheim are closely related to Gombrich academically. Among them, Erwin Panofsky is the highest frequency co-cited author of Gombrich with 781 times. It followed by Nelson Goodman with totally 463 times. The third is Rudolf Arnheim with totally 435 times.

These 29 authors can be regarded as the main affinitive authors' group of Gombrich, namely Gombrich's core academic affinitive community. The community members are mainly from Europe including UK, Germany, France, Italy and 1/4 of them are from the United States. 
TABLE I. GOMBRICH HIGH CO-CITED LIST OF AUTHORS (THRESHOLD $\geq 160$ )

\begin{tabular}{|c|c|c|c|}
\hline $\begin{array}{c}\text { Co-cited } \\
\text { Frequency }\end{array}$ & Author & Countries & $\begin{array}{l}\text { Main Study } \\
\text { Discipline }\end{array}$ \\
\hline 781 & Erwin Panofsky & U.S.A & $\begin{array}{l}\text { Studies in } \\
\text { Iconology }\end{array}$ \\
\hline 463 & Nelson Goodman & U.S.A & $\begin{array}{l}\text { Analytic } \\
\text { Aesthetic }\end{array}$ \\
\hline 435 & Rudolf Arnheim & Germany & $\begin{array}{c}\text { Gestalt } \\
\text { Psychology }\end{array}$ \\
\hline 377 & Giorgio Vasari & Italy & Art History \\
\hline 364 & Roland Barthes & France & $\begin{array}{l}\text { Semiotics and } \\
\text { Philosophy }\end{array}$ \\
\hline 346 & Michael Baxandall & Britain & $\begin{array}{l}\text { Studies in } \\
\text { Iconology }\end{array}$ \\
\hline 316 & Sigmund Freud & Austria & $\begin{array}{c}\text { Analysis of } \\
\text { Psychoanalysis }\end{array}$ \\
\hline 305 & Michel Foucault & France & $\begin{array}{c}\text { Philosophy and } \\
\text { Sociology }\end{array}$ \\
\hline 271 & $\begin{array}{l}\text { James Jerome } \\
\text { Gibson }\end{array}$ & U.S.A & Psychology \\
\hline 257 & $\begin{array}{l}\text { Leone Battista } \\
\text { Alberti }\end{array}$ & Italy & Architecture \\
\hline 249 & Umberto Eco & Italy & $\begin{array}{c}\text { Philosophy and } \\
\text { Semiotics }\end{array}$ \\
\hline 246 & Richard Wollheim & Britain & $\begin{array}{l}\text { Analytic } \\
\text { Aesthetic }\end{array}$ \\
\hline 243 & Edgar Wind & Britain & $\begin{array}{l}\text { Studies in } \\
\text { Iconology }\end{array}$ \\
\hline 234 & $\begin{array}{l}\text { Karl Raimund } \\
\text { Popper }\end{array}$ & Britain & $\begin{array}{l}\text { Philosophy of } \\
\text { Science }\end{array}$ \\
\hline 229 & $\begin{array}{l}\text { Richard Langton } \\
\text { Gregory }\end{array}$ & Britain & Psychology \\
\hline 225 & Jacques Derrida & France & Philosophy \\
\hline 222 & $\begin{array}{c}\text { Ludwig Josef } \\
\text { Johann Wittgenstein }\end{array}$ & Britain & $\begin{array}{c}\text { Analytic } \\
\text { philosophy }\end{array}$ \\
\hline 221 & Walter Benjamin & Germany & Philosophy \\
\hline 210 & $\begin{array}{l}\text { William John } \\
\text { Thomas Mitchell }\end{array}$ & U.S.A & Art History \\
\hline 200 & Aby Warburg & Germany & $\begin{array}{l}\text { Studies in } \\
\text { Iconology }\end{array}$ \\
\hline 195 & Ernst Kris & Austria & Psychology \\
\hline 190 & Rudeolf Wittkower & Germany & $\begin{array}{l}\text { Studies in } \\
\text { Iconology }\end{array}$ \\
\hline 189 & Aristotle & $\begin{array}{l}\text { Ancient } \\
\text { Greek }\end{array}$ & Philosophy \\
\hline 186 & Meyer Schapiro & U.S.A & Art History \\
\hline 186 & $\begin{array}{l}\text { Arthur Coleman } \\
\text { Danto }\end{array}$ & U.S.A & Philosophy \\
\hline 179 & Heinrich Wolfflin & Switzerland & Art History \\
\hline 175 & André Chastel & France & Art History \\
\hline 173 & Leonardo Da Vinci & Italy & $\begin{array}{c}\text { Multi- } \\
\text { Disciplines }\end{array}$ \\
\hline 167 & $\begin{array}{l}\text { Thomas Sammual } \\
\text { Kuhn }\end{array}$ & U.S.A & $\begin{array}{l}\text { History of } \\
\text { Science }\end{array}$ \\
\hline
\end{tabular}

\section{DATA ANALYSIS}

\section{A. The Chronicle of Affinitive Community}

The time series of the first co-cited year of the related authors and Gombrich can reflect Gombrich's academic affinitive relationships in different periods. Table II and Figure I show the statistics based on this concept.

TABLE II. THE SERIES OF THE FIRST CO-CITED YEAR OF ACADEMIC AFFINITIVE COMMUNITY MEMBERS

\begin{tabular}{|c|c|c|}
\hline $\begin{array}{l}\text { The First Co- } \\
\text { cited year }\end{array}$ & $\begin{array}{c}\text { The Co- } \\
\text { cited times }\end{array}$ & Author Name \\
\hline 1950 & 316 & Sigmund Freud \\
\hline 1950 & 195 & Ernst Kris \\
\hline 1958 & 781 & Erwin Panofsky \\
\hline 1959 & 186 & Meyer Schapiro \\
\hline 1960 & 173 & Leonardo Da Vinci \\
\hline 1960 & 234 & Karl Raimund Popper \\
\hline 1961 & 435 & Rudolf Arnheim \\
\hline 1961 & 271 & James Jerome Gibson \\
\hline 1961 & 179 & Heinrich Wolfflin \\
\hline 1965 & 377 & Giorgio Vasari \\
\hline 1965 & 222 & Ludwig Josef Johann Wittgenstein \\
\hline 1965 & 221 & Walter Benjamin \\
\hline 1965 & 167 & Thomas Sammual Kuhn \\
\hline 1966 & 243 & Edgar Wind \\
\hline 1966 & 200 & Aby Warburg \\
\hline 1966 & 189 & Aristotle \\
\hline 1966 & 190 & rudeolf Wittkower \\
\hline 1968 & 186 & Arthur Coleman Danto \\
\hline 1969 & 339 & Roland Barthes \\
\hline 1969 & 346 & Michael Baxandall \\
\hline 1969 & 305 & Michel Foucault \\
\hline 1969 & 257 & Leone Battista Alberti \\
\hline 1969 & 229 & Richard Langton Gregory \\
\hline 1969 & 175 & André Chastel \\
\hline 1970 & 463 & Nelson Goodman \\
\hline 1970 & 246 & Richard Wollheim \\
\hline 1976 & 249 & Umberto Eco \\
\hline 1976 & 225 & Jacques Derrida \\
\hline 1977 & 210 & William John Thomas Mitchell \\
\hline
\end{tabular}

Figure I shows the bigger the dot, the stronger the relationship between scholars and Gombrich, the farther the horizontal distance between dots and coordinate, the later the establishment of academic affinitive relationship with Gombrich. It can be seen that Gombrich's academic affinitive author first appeared in the early 1950s, the related author mainly are Freud, Chris, Panofsky and Shapiro. But only Panofsky has the closest affinitive relation with Gombrich. Freud and Chris are the earliest authors who established the relation. But later the strength of the relationships decreased; 
1960s is the peak period for generating Gombrich's affinitive authors, which mainly are artists, philosophers and iconology researchers including Leonardo, Vasari, Gibson and Arnheim, etc. After 1970s, the new affinitive authors get fewer. Although the establishment of the relationships between Goodman and Gombrich's is relatively late, the strength of the relationship is only second to Panofsky.

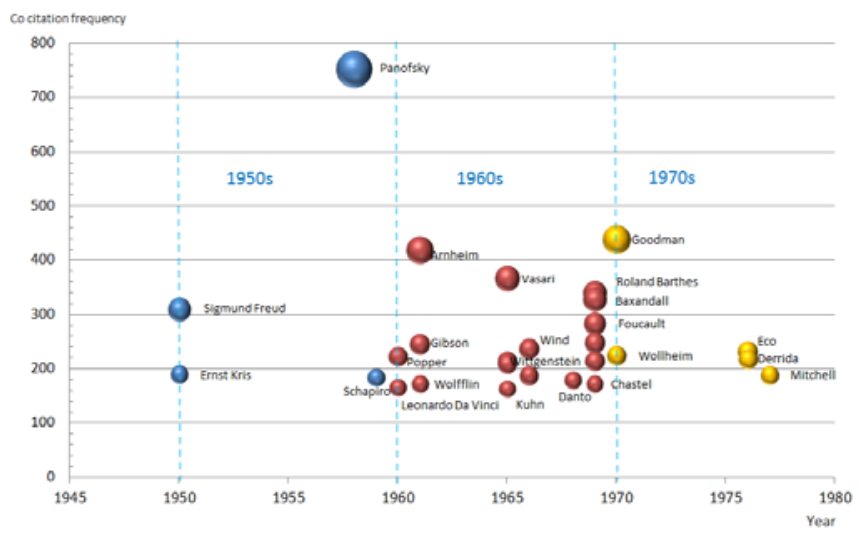

FIGURE I. ACADEMIC AFFINITIVE COMMUNITY MEMBERS AND GOMBRICH'S FIRST CO-CITED CHRONICLE SERIES

\section{B. Academic Affinitive Community Cluster Relationship}

With the assistance of Bibexcel and VOSviewer, the data matrix is analyzed. Figure II shows the clustering relationship of Gombrich's highly co-cited authors.

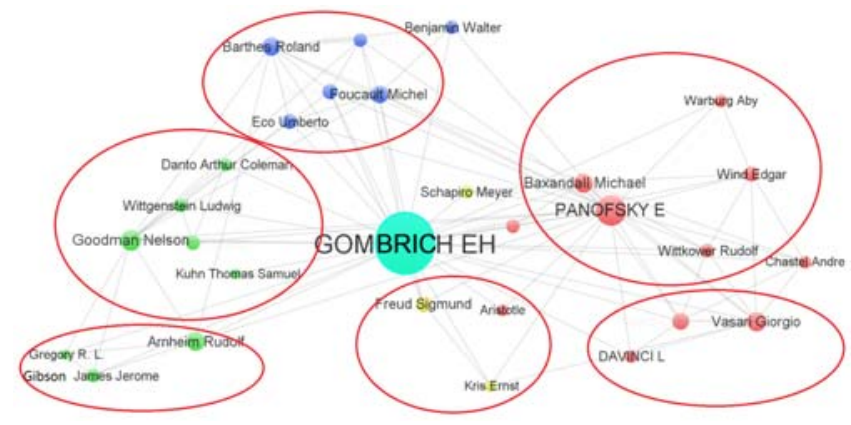

FIGURE II. DISTRIBUTION DIAGRAM OF THE HIGH CO-CITED AUTHORS OF GOMBRICH

With Gombrich as the center, this diagram automatically generates many clusters according to the co-cited correlation of authors, such as the red circles divide all the authors into six close clusters.

Through the analysis of the academic background and the main works of all the related authors, it is found that Gombrich's core community can be summarized as six research groups: Iconology research group of Warburg school: main representatives are Panofsky, Aby Warburg, Edgar Wind, Michael Baxandall and Rudeolf Wittkower. Philosophy research group of analytic aesthetics: main representatives are Richard Wollheim, Nelson Goodman, Wittgenstein, Kuhn and Danto.Psychological research group of visual \& perceptual theory: main representatives are Rudolf Arnheim, James Gibson, Richard Gregory and Jean Piaget. Research group of
Psychoanalysis: the main representatives are Sigmund Freud and Ernst Kris. Semiotics research group of post-structuralism: Michel Foucault, Roland Barthes, Umberto Eco, Jacques Derrida, and Ernst Cassirer, etc.; The Italian art masters group in each period with Leone Battista Alberti, Leonardo Da Vinci, Vasari and Ovidius.

\section{1) Iconology Research Group of Warburg School}

Erwin Panofsky, Aby Warburg, Edgar Wind,Rudeolf Wittkower and Michael Baxandall share the same academic relationship in some degree. They all have worked in the Warburg Institute where the iconology research community of Warburg school formed. It was founded in Hamburg, formerly Warburg library. It can be regarded as the first iconology research institute in the world. The institute moved to London during World War II. Therefore, Gombrich moved from Vienna to the Warburg Institute, University of London. He was responsible for finishing the work of art manuscripts. Thus, Gombrich's ideas collided with iconology which has an profound influence in his subsequent academic career.

\section{2) Philosophy Research group of Analytic Aesthetics}

Analytic aesthetics studies the languages and concepts used in literary and artistic criticism, namely, the philosophical analysis of the concept, especially the terminology. The main representatives of this school are Wittgenstein, Richard Wollheim and Nelson Goodman who are all academic affinitive authors of Gombrich. Ludwig Josef Johann Wittgenstein (1889-1951) is the pillar representative of analytic philosophy and language, His research fields are mathematical philosophy, psycho-philosophy and philosophy of language. Since the beginning of twentieth century, under the influence of Wittgenstein's philosophy thoughts, the school of "Analytic Aesthetics" has been founded and it occupied a dominant position in the Anglo-American aesthetics field till the end of twentieth century. Nelson Goodman (1906-1998) is a core figure among Anglo-American analytic aestheticians. His "Language of Art" is to discuss the characteristics and essence of classic artworks, which criticized the art analysis of symbolic aesthetics [5]. After the publication of the book, Gombrich said he did not agree with Goodman's thought. Goodman united the image and symbol on the basis of a certain program. He thought that the image can be considered as a conventional symbol. Both Goodman and Gombrich argued over the image whether it is a conventional (or programmed) symbol or a natural symbol.

\section{3) Psychological Research Group of Visual \& Perceptual} Theory

Sharing the background of psychology, the authors of the group are from the school of Gestat psychology and cognitive psychology etc. The main representatives are: Rudolf Arnheim, James Gibson, Richard Gregory, Jean Piaget etc. Rudolf Arnheim (1904-2007), born in Germany, is an American psychologist and scientist. Gombrich and Arnheim was deeply influenced by Austro-German rational spirit and psychological tradition. They both have made unique contributions respectively in the visual \& perceptual psychology of art. Jean Piaget (1896-1980) and his cognitive development theory has set a model of the discipline, he paid attention to the concept of Schemas in cognitive development theory and proposed the 
concept of "cognitive schema", which is considered as a cognitive structure arising when people try to cope with a particular situation. Piaget's thoughts as "cognitive theory", "schema" theory and children's psychology have close academic correlation with Gombrich's research, and have an important impact on Gombrich's academic thoughts.

\section{4) The Author Group of Psychoanalysis}

Freud and Kris belong to the school of psychoanalysis. Although they are in the field of psychology research, lacking of the correlation with psychological researchers of visual \& perceptual in Gombrich's co-cited network, they will be discussed respectively as follows. Ernst Kris (1900-1957) is a close friend of Gombrich, his later theoretical research mainly concentrated in the field of psychoanalysis theory, selfpsychology, early childhood development and psycho analysis etc. Based on the work partnership and friendship with Freud and Gombrich, they established close academic relations, especially on the influence of Gombrich's art psychology, Ernest Kris played a key role. The academic relationship between Gombrich and Freud was first set up by Kris as a bridge, through exchanges and cooperation with Kris, Gombrich learned a lot of knowledge of psychology, his research largely benefited from Freud's psychological analysis, such as the correlation between Freud's projection theory and Gombrich's subjective projection theory. As Freud have applied projection theory in the study of empathy in psychology, therefore, Gombrich applied his researches into the study of visual art, he believes that art creation and appreciation cannot be without the performance of the projection mechanism based on psychological orientation. Gombrich proposed the theory of "subjective projection" that the artist tends to find their own literacy style and quality as the motif they are ready for.[6]

\section{5) Semiotics Research Group of Post-structuralism}

After 1960s, in France and Italy as the center, semiotics research was popular again across European counties. After that, it entered the field of art history and art criticism, which had a significant meaning to the study of art history. In 1970s, post structuralism rose up in France, the representatives of post structuralism semiotics are mainly from structuralism. They are also related to Gombrich and emphasize the relationship of interwoven and interaction between context and text. The main representatives are Michel Foucault, Roland Barthes, Umberto Eco, Derrida Jacques and Ernst Cassirer. Foucault emphasized the need to re-search for narrative syntax and visual cognitive approach in the history of art. Through interpreting the painting and literary creation as a symbol, he provides a philosophical perspective for the iconology and semiotics.

Under the background of "The Linguistic Turn" in twentieth century, Cassirer developed a unique set of cultural semiotics, he also wrote a work series of epistemology, scientific theory and history of philosophy. His major works are "Freedom and Form" and "Mythical Thought" etc. Cassirer is a member of the Warburg Institute, and he established a profound friendship with Panofsky. They shared the NeoPlatonism of Renaissance and the common interests of philosopher Kant. These ideas have a great influence on Panofsky which have academic intersection and inheritance relations with iconology research of Warburg school. [7].

\section{6) The Italian Art Masters group in Each Period}

Giorgio Vasari, Leone Battista Alberti, Leonardo Da Vinci and Ovidius, these masters of the arts and literatures are the academic affinitive authors of Gombrich too.

Gombrich's academic thoughts have an internal inheritance and logic relations with Vasari's theory. From Gombrich's view, the purpose of history of art is to trace its origin. This tradition is established by Vasari. The traditional art history writing pattern of Vasari and Gombrich sets an ultimate goal or a comprehensive core concept, which means interpreting the artwork placed in a proper historical position. Vasari's concept about the artist and artwork "style" has profound influence and significance to the study of modern western art history and art historians including Gombrich.

Leone Battista Alberti (1404-1472) is an Italian architect and architectural theorist. $\mathrm{He}$ is the most influential architectural theorist in the Renaissance Italy. His "Theory of Painting ", first published in 1435, is the first systematic work of Western painting. Modern researchers generally discuss the book and his theory in the scope of art theory rather than in history [8]. This book has played an important role in the western art history and directs the development of art history study.

Leonardo Da Vinci (1452-1519) is an outstanding art master in the midterm Renaissance Italy. He is also a scientist and engineer. His biggest contribution is to use the light and shade to create three-dimensional space and sense from twodimensional pictures. Apart from this, he has a huge contribution to artistic innovation such as the composition method, perspective and psychological description. Gombrich did a comprehensive discussion and in-depth research on Leonardo. The works of Leonardo are widely used as examples in Gombrich's books and papers such as "The Story of Art" and "Art and Illusion".

\section{7) Other Related Affinitive Authors}

In addition, Gombrich's academic affinitive authors also include Popper, Wolfflin, Aristotle, Walter Benjamin, Shapiro and Chatel. Although they are not strictly belong to a certain group which is mentioned above, their affinities with Gombrich are very strong, and have important influence in the process of Gombrich academic diffusion.

Karl Popper (1902-1994) is an important science philosopher accounting for Gombrich's thought formation. He provides the academic and theoretical basis for the formation of Gombrich's core ideas through their long-term friendship and academic exchanges. Gombrich selected Popper's falsificationism, the method of trial and error, epistemology and the theory of three worlds as the basic starting point in the development of psychology and cognitive theory of art. And he has developed the theories such as logic of art history, art visual cognition, the theory of changing styles and artistic value theory. From the citation performance, Popper's books has become important co-cited literatures with Gombrich, namely "The Logic of Scientific Discovery", 1959; "The Open Society and Its Enemies", 1945; "The Poverty of Historicism", 1957; " Unended Quest: Intellectual Autobiography", 1976; "Knowledge: Objective Evolutionary Approach", 1972; 
"Conjectures and Refutations: The Growth of Scientific Knowledge", 1963.

Meyer Schapiro (1904-1996) is the representative of the post-iconology study. With the inspiration of iconology science, He studies the modern art with the method of multi-discipline integration. According to the Gombrich high co-cited diagram, he is a comprehensive researcher. The distribution of authors shows that his study is similar to the iconology cluster and psycho-analysis school. So his position in the co-cited network is not fixed which means he does not strictly belong to any research group.

\section{CONCLUSION}

Gombrich's academic affinitive community is divided into six groups. It can be found that Gombrich's academic thoughts have strong features of inheritance, intersection and comprehension. And his source of ideas and discipline ascription dabbled in multi-dimensional areas including iconology, philosophy, semiotics, psychology etc. He and his academic affinitive authors formed the discipline divergent forces in different fields, which the diffusion of his academic thoughts has wide-area theoretical background. Gombrich's core academic affinitive community has the following characteristics:

1960s is the key 10 years for the establishment of the relationships between Gombrich and his affinitive authors which represents Gombrich's academic status has been revealed from the beginning of 1960s. In 1950s, the affinitive authors mainly include Freud, Kris, Panofsky and Shapiro, but only Panofsky and Gombrich have a close relationship. 1960s is the peak period for the generation of Gombrich's affinitive authors who is mainly from artists, philosophers and iconology scientists. In the contrary, a few of new affinitive authors appeared since 1970s. Although the establishment of relationship between Goodman and Gombrich is relatively late, the relationship is only second to Panofsky.

Gombrich's academic affinitive community members are mainly from Europe, it can be seen that the academic origin and academic affinitive origin began in Europe. Among them, the European countries mainly are the United Kingdom, Germany, France, Italy and another $1 / 4$ of the community members are from the United States.

Gombrich's affinitive authors are masters in various fields of studies. Their academic thoughts have taken leading roles in their respective fields while occupying the core academic positions, which can be proved that Gombrich's master status and academic charisma. Meanwhile these outstanding scholars and masters formed strong theoretical backing and academic background for Gombrich's academic thoughts.

\section{REFERENCES}

[1] Fan Jingzhong, "Art Historian— The Biography of Gombrich," New Art, vol. 4, pp. 66-72,1988.

[2] G. Horowitz, "Ernst Gombrich, " Shen Tu Yanyan trans. New Art, vol.4, pp. $4-8,2009$.

[3] Kaplan N, "The norms of citation behavior: Prolegomena to the footnote ," American Documentation, vol. 3, pp. 179-184,1965.
[4] Smith L C, "Citation analysis , ".Library Trends, vol. 30, pp.83$106,1981$.

[5] Nelson Goodman, Languages of Art: An Approach to a Theory of Symbols Languages. Peng Feng trans.Beijing: Peking University Press, 2013.

[6] Gombrich.E.H. Art and Illusion. Yang Chengkai, Li Benzheng, Fan Jingzhong Trans. Guangxi: GuangXi Fine Arts Publishing House, 2012.

[7] Yu Huoxing, "Zhang Shouyu. Image Study Method in Modern Western Art Research ," Hundred schools in arts, vol. 3, pp. 177-181,2012.

[8] Cao Yiqiang. "De Pictura of Leone Battista Alberti andCommentarii of Lorenzo Ghiberti”. New Art. vol. 3, pp. 28-36,2001. 